\title{
The Impacts of Globalization on Environmental Security in Vietnam Today
}

Mrs. Le Thi Thanh $\mathrm{Ha}^{*}$

Associate Professor, Institute of Philosophy, Ho Chi Minh National Academy of Politics, 135 Nguyen Phong Sac, Cau Giay, Hanoi, Vietnam

\section{Article History}

Received: 12.10 .2020

Accepted: 28.10 .2020

Published: 04.11.2020

Journal homepage:

https://www.easpublisher.com/easjhcs

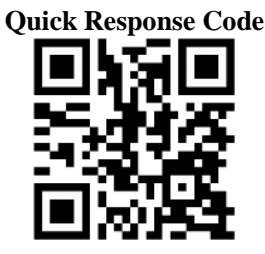

Abstract: In recent years, the issue of environmental security is emerging as an urgent phenomenon of social life. In Vietnam, environmental quality is changing in an unfavorable direction to life. Without keeping environmental security, there is no existence and development of human beings or human society. One of the reasons for environmental insecurity is the negative impact of globalization. Therefore, the article points out the negative effects of globalization on environmental security, and on that basis offers a number of solutions to maintain environmental security in Vietnam in the context of globalization the current.

Keywords: Globalization, environmental security.

Copyright (C) 2020 The Author(s): This is an open-access article distributed under the terms of the Creative Commons Attribution 4.0 International License (CC BY-NC 4.0) which permits unrestricted use, distribution, and reproduction in any medium for non-commercial use provided the original author and source are credited.

\section{INTRODUCTION}

There are many notions of globalization. In our opinion, globalization is the increase of relationships, links, interdependencies and mutual covenants among all countries in the international community.

Globalization is a highly developed stage of internationalization that took place many centuries ago and is taking place strongly in the twenty-first century. The trend of globalization stems from the development of production forces, from the socialization of production forces on a national and international scale. The direct cause and also the manifestation of the globalization trend is due to the strong impact of transnational monopolistic companies and these companies are now the dominant force in globalization the current.

Most scientists in the world and Vietnam believe that today, globalization is affecting all areas of social life, such as economics, politics, culture, education and specialties especially the living environment. Everywhere people feel clearly the effects of globalization in both positive and negative directions. How positive and how negative depends on specific areas, conditions and historical context of each country in the international community. Vietnam is a developing country participating in the globalization process, contributing to the promotion and development of various fields.
In the economic field, globalization promotes the extensive development of international economic relations, creating opportunities for each country to take advantage of the world market for its production and business activities. Globalization opens the possibility for countries, especially developing countries like Vietnam, to quickly and effectively participate in the international division of labor, from which all sources can be utilized resources, serving our national development goals. As a result, Vietnam can accelerate the process of structural adjustment of the economic sector and shorten the material time of industrialization, modernization, life improvement and enhancement of Vietnam's position in the marketplace world.

Globalization encourages Vietnam to exchange international culture and knowledge, enhances mutual understanding, mutual trust and friendship with nations in the world. Thanks to globalization, universal values are human - civilized values are pouring into Vietnamese culture, raising Vietnamese society to a higher level of civilization, increasing the universality of humanity.

However, the process of globalization is also affecting many areas of development in Vietnam. In the economic field, developing countries such as Vietnam are subject to the rules of commerce, finance, and currency ... set by developed countries. On the social side, globalization on the one hand brings an insatiable 
wealth to developed countries, which have advantages and know how to take advantage of opportunities brought about by globalization. Besides, many Vietnamese people in remote and isolated areas have hardly enjoyed the fruits of globalization. In fact, they are impoverished, pushed into chronic unemployment, lack of education, access to health care, access to clean water and the social security system, which means they are suffering marginalization of developed society. In the field of culture, globalization loses national cultural identity due to the "cultural invasion" of big countries towards small countries. Globalization in addition to the positive impacts on the field of environmental security in Vietnam such as: applying new technologies in production reduces environmental pollution, avoids wasting resources; access to modern environmental treatment technology to contribute to environmental protection; promote linkages between countries to solve environmental problems. Besides, globalization is also contributing to environmental pollution, climate change and the risk of causing environmental insecurity in Vietnam male in recent years.

\section{RESEARCH CONTENT}

Globalization promotes economic development at all costs, leading to the consequences of maximum exploitation of resources, contributing to the loss of environmental security

Globalization has created conditions for Vietnam to develop economy through import and export. According to National Treasury Management Magazine No. 168 (6/2016), if in 2007, the total importexport turnover of Vietnam was 111.3 billion USD (of which exports were 48.5 billion USD and imported Export turnover is 62.7 billion USD), by 2015 the total import-export turnover of Vietnam has increased about 3 times to reach 328 billion USD (of which import is 165.6 billion USD and export is 162.4 billion USD) $\left[{ }^{1}\right]$. In 2019, the statistics of the Import and Export Department show that the average import-export turnover is about 43 billion USD / month. The total import-export turnover in 2019 is estimated at 516.96 billion USD, up $7.6 \%$ (equivalent to 36.69 billion USD) compared to $2018\left[^{2}\right]$ and nearly double compared to 2015.

However, Vietnam is a country with a low level of production force, so its exports are mainly natural resources and raw minerals. For example: exports in 2019, wood and wood products increased by 1.74 billion USD, respectively, by $19.5 \%$; precious

\footnotetext{
${ }^{1}$ See: The impact of international economic integration on Vietnam's economy, Journal of Finance, No. 168 (6/2016).

${ }^{2}$ To Uyen: In 2019: Exports grew impressively in both 'quantity' and 'quality', http://thoibaotaichinhvietnam.vn/, dated December 26, 2019.
}

metal stones and products increased by 1.45 billion USD, respectively by 3.3 times, coal of all kinds increased by 1.24 billion USD; crude oil increased by 849 million USD $\left[{ }^{3}\right]$. Meanwhile, Vietnam mainly produces and exploits using outdated technology, leading to loss and waste of natural resources, causing environmental pollution, climate change, contributing to environmental insecurity. According to the Institute of Development Consultants (CODE), the loss of resources in the exploitation process in Vietnam is at a very high level. The loss of pit coal mining is up to 40 $60 \%$, apatite exploitation $26-43 \%$, metal ores $15-30 \%$, building materials $15-20 \%\left[{ }^{4}\right]$. This shows that the process of globalization has strongly stimulated benefits, especially the economic interests of each entity in the market economy, contributing to many consequences for the environment. A lot of evidence in Vietnam over the past time shows that, where is rich in mineral resources, it is easy to create conflicts, conflicts of economic interests and environmental interests.

Globalization has boosted the seafood export demand, in which the aquaculture industry has thrived in the past 30 years. Vietnam not only breeds in rivers, lakes, lagoons, lagoons ... but also goes to the sea. But because livestock is still spontaneous, there is no pollution treatment system, so the water resources in these places are seriously polluted. The untreated residues of chemicals and antibiotics used in the farming process will form a bottom sludge layer due to the long-term accumulation of organic matter, and the residue is inhabited by microorganisms. pathogenic microorganisms such as Vibrio, Aeromonas, Ecoli, Pseudomonas, Proteus, Staphylococcus ... and toxic gases such as $\mathrm{NH} 3, \mathrm{NO} 2, \mathrm{H} 2, \mathrm{H} 2 \mathrm{~S}, \mathrm{CH} 4$, affecting water security.

Deforestation in Vietnam has been going on for a long time. But now, because Vietnam's economy is on the way of developing, while the economic conditions of the people have not changed towards progress, along with that, the import and export of wood products has also increased. Therefore, the level of deforestation is getting heavier. Many poor people in need, go to the forest to cut timber, smuggling to make money. Forests are cut down, not only reducing the air quality for life and greenness on Earth. Which entails a series of consequences people are suffering. The loss of forest means that dangerous natural disasters like EL Nino and La Nina continuously occur. Flash floods, watershed floods, landslides, climate change, and most importantly, destroys the habitats of all species on earth.

\footnotetext{
${ }^{3}$ General Department of Customs: An overview of Vietnam's import and export activities in 2019, https://haiquanonline.com.vn/.

${ }^{4}$ See: Shortcomings and consequences from mining, https://www.thiennhien.net/, dated 10/05/2011.
} 
The area of forests, especially natural forests in Vietnam, is being narrowed alarmingly. This leads to an increasing rate of extinction of some species. The inevitable consequence is to reduce / lose the functions of the ecosystem such as water regulation, anti-erosion, waste disposal, clean the environment, ensure material and energy circulation in the mitigation of natural disasters / extreme climate consequences. And, ultimately, the economic system will be impaired due to the loss of environmental security, the loss of the value of natural resources. According to statistics of the Forest Protection Department (MARD), the forest coverage in 2015 reached $40.43 \%$, of which the primary forest area was only about $10 \%\left[^{5}\right]$.

To meet globalization demand, the livestock and product processing industries, fisheries, livestock and poultry have increased in Vietnam. But also due to the development of livestock in the absence of initial planning, many livestock, slaughterhouses and food processing enterprises are still mixed in residential areas, and livestock production is still small, fragmented, and fecal. While agricultural production has low profits, prices are unstable, the market is less stable ... so investment in environmental treatment in livestock production is very low, leading to a polluted environment as animal husbandry continues to take place in many parts of the country.

The impact of globalization promotes the application of new scientific and technological advances to agricultural production. However, the level of management and production organization is still low, so there are many harms arising from the improper use of chemical fertilizers, plant protection chemicals ... or overuse environmental pollution, affecting human health and life. According to the calculations of scientists, the source of waste entering the environment from cultivation tends to increase in Vietnam in recent years, while the control is not effective. Most worrying is waste from fertilizers. Currently the country has 26 million hectares of cultivated land the total amount of fertilizers used is from 10 to 11 million tons / year. According to calculations by the authorities, the efficiency of using nitrogen fertilizer when fertilizing the soil is only 30-45\%; phosphate fertilizer $40-45 \%$; Potassium 40-50\% depending on soil quality, cultivar, season, method of fertilization, type of fertilizer. From this fact, the authorities estimate that the use of fertilizers is wasting 30,000 billion VND / year. More worrying, a large amount of residue due to not being absorbed by plants will negatively affect agricultural ecosystems, pollute water and soil sources and possibly cause environmental insecurity.

\footnotetext{
${ }^{5}$ Ministry of Natural Resources and Environment: National environmental status report 2011-2015, Hanoi 2015, p. 144.
}

Expanding globalization is a condition for traditional craft villages to gradually develop and expand. That development was not accompanied by waste treatment measures, thus causing serious pollution of the craft village environment. Currently there are 1,450 craft villages nationwide, distributed in 56 provinces. The majority of craft villages are polluted by production wastes, dust, toxic gases, residues and wastewater discharged. Because the level of technology and equipment are mostly out of date, patchy, lack of sync and infrastructure is limited. It is a fact now that the increasing number of cancer villages detected is causing more insecurity among the people and causing environmental insecurity.

\section{Globalization accelerates the process of "ecological aggression" that threatens environmental security}

Vietnam is a developing country, decades behind developed countries, in the current globalization conditions, taking advantage of loopholes, shortcomings, inadequacies in the legal system and weaknesses in economic management. In terms of economics, social management, many Vietnamese state management officials have assisted criminals, assisted "ecological aggression" such as import of industrial scrap, import of foreign creatures hybridization, import of agricultural products containing toxic chemicals, ... turn Vietnam into industrial and agricultural landfills.

According to calculations by the Ministry of Industry and Trade, currently $70 \%$ of machinery and equipment imports are from countries with intermediate technology. The import of this old generation equipment and machinery is increasing the phenomenon of emissions and waste. Especially in recent years, the worrying situation is an increase in the import of scrap and second hand goods into our country such as scrap steel, scrap paper, plastic packaging, used electronics and computers old.

In addition, globalization also contributes to accelerating disturbances of many ecosystems, because the invasion of foreign organisms and genetically modified organisms is quite common in Vietnam, affecting safety national environmental security. For example, in 2000, beaver rats were imported for experimental farming in Vietnam. This is the species listed in the list of 100 most dangerous invasive species in the world. The beaver rats carry pathogens such as tuberculosis, tuberculosis, tuberculosis, skin tuberculosis ... causing disease in humans and animals, adversely affecting other animals. Although when detecting harmful to the ecological environment beaver rats have been destroyed but still and affect the current ecosystem of our country. Besides, red lobster, land cockroach, red ear turtle, yellow snail, black velvet weasel ... are alien creatures that can cause serious consequences on the list of banned import and not being 
produced business in Vietnam but still exists and has a negative impact on the environment.

Behind the introduction of outdated technology and the introduction of genetically modified harmful organisms into Vietnam in recent years, globalization has also demonstrated ecological warfare schemes, threatening environmental security in Vietnam. Poor countries like Vietnam are very vulnerable to this trap. The fact that people who depend on forests, rely on ecological resources, now have to go to other countries to make a living is understood as environmental insecurity. Because, environmental degradation leads to environmental refugees. Resourcebased communities, when they lose ecological services, no longer make a living, they become environmental refugees in other urban areas or go abroad to make a living. In many provinces near the border, when people cannot rely on ecological resources, they will find ways to work for other countries, becoming environmental vices. Although the problem of transboundary air pollution has not been clearly shown, certain signs of influence appear.

\section{Globalization accelerates the spread of disease globally, affecting the security of the living environment of the people}

Globalization makes the travel process easier, faster and more convenient, and this is also a condition for the disease to spread quickly, seriously threatening the security of the living environment of the people. The commercial exchanges, population mobility, also tend to be ... globalization. The Covid-19 epidemic happening around the world today is a typical example of this problem. The epidemic is not limited to China, but has spread across the globe at an unprecedented speed in history. There are more than tens of millions of people infected with the number of deaths rapidly increasing to nearly 1 million people worldwide.

In Vietnam, the Covid-19 epidemic not only affects the economy such as the aviation, tourism, services, trade, investment, ... but most importantly, the epidemic is threatening people's living environment. According to research of scientists, in the future, it is very likely that infectious and dangerous viruses such as SARS-CoV-2 will appear due to climate change and environmental insecurity. The loss of habitat and biodiversity has allowed new viruses and diseases such as Covid-19 to spread into the community. In addition, due to the impact of globalization, the global transport network has made the epidemic disease, which was supposed to only occur in one region, can now spread to many areas in a short time pandemic Covid - 19 . Therefore, maintaining environmental security is a vital task of humanity and all Vietnamese people in the present conditions. If environmental security cannot be kept, environmental disasters will weaken the economy, increase poverty, increase political instability, especially, increase diseases such as the Covid-19 pandemic detonators for social unrest, conflicts, wars and even destruction of humanity.

Globalization has increased people's lives, has boosted the demand for travel, travel and freight, many people have increased motorized vehicles the number of traffic accidents has also increased up. In addition, due to the high demand for tourism leading to the spread of diseases, dangerous diseases such as HIV / AIDS, severe acute respiratory infections syndrome SARS, Ebola, influenza ... are clear examples most on the negative impact of global liberalization in tourism, travel and immigration on the health and security of the human environment. For example, the SARS epidemic broke out in Hong Kong in 2003, within a few weeks SARS had infected many others in 37 countries around the world and nearly turned into a pandemic. There are 8422 illnesses and 916 deaths worldwide $\left[{ }^{6}\right](10.9 \%$ deaths). In Vietnam, the SARS epidemic has caused 44 nurses and doctors of the Vietnam French Hospital to spread the disease, and 6 people (domestic and foreign) have died. The Vietnamese French hospital had to be disinfected and closed for nearly half a year.

Globalization makes it easier for frozen and processed products to be imported into Vietnam. These foods have the risk of containing toxic chemicals, bacterial infections, heavy metals, pesticides or antibiotics ..., even being counterfeited, do not meet food safety requirements to people's health. Authorities in China and other countries have discovered a series of food poisoning cases: methonyl (insecticide) in 18 teas; formaldehyde to keep vegetables fresh; sodium nitrate, urea and growth hormone in cowpea, raw bean; toxic chemicals and additives to make fake duck blood; high lead content in spirulina, dried fruit and apricot; animal fats and kitchen waste for cooking oil recycling; industrial gelatin for processing fake pig ears; Specially use the remains of fetus, newborn baby, placenta to produce "medicine" for weight loss, beauty, and functional foods. These foods contribute to increasing the risk of cancer, increasing the rate of obesity, causing complications, blood fat, heart.

In general, the above negative impacts from globalization are contributing to environmental insecurity and threats to the environment of people on this planet in general and in Vietnam in particular.

\section{CONCLUSION}

In Vietnam, ensuring environmental security is considered one of the regular and long-term tasks of both the political system and the entire society. At the XI Congress, our Party affirmed: "Environment

\footnotetext{
${ }^{6}$ Ministry of Health (2017), Guidance on monitoring of serious acute respiratory infections (SARI), Decision 1271 / QD-BYT-2017
} 
protection is the responsibility of the entire political system, the entire society and all citizens" $\left[{ }^{7}\right]$. In addition, the concept of environmental security has been included in the Law on Environmental Protection 2014. The issue of environmental protection and response to climate change is also an important content of the document of the Party Congress XII, which emphasized: "Preventing and gradually overcoming the degradation of the natural environment caused by humans, especially by economic development projects to limit and proceed to basically overcome the destruction and depletion of natural resources and environmental pollution of production establishments, industrial parks and urban areas. Complete the legal system, enact strong enough sanctions to protect the environment, prevent and handle according to law to end the situation of causing environmental pollution, strengthen prevention and control of sources of pollution environmental contamination" $\left[{ }^{8}\right]$. At the same time: "ready to respond to traditional, nontraditional security threats" $\left[{ }^{9}\right]$. This shows that, in recent years, the issue of ensuring environmental security has been concerned by the Party and State of Vietnam and institutionalized in the guidelines, policies and laws.

However, Vietnam's environment is still heavily polluted, threatening national security. Document of Congress XI affirms: "Non-traditional security threats, high-tech crime continue to increase. Global issues such as financial security, energy security, food security, climate change, natural disasters, epidemics will continue to develop complicatedly" $\left[{ }^{10}\right]$. Besides: "Tensions, religious conflicts, ethnicity, separatism, local war, political riots, interference, overthrow, terrorism will still take place fiercely; Non-traditional security threats, high-tech crimes in the fields of finance - money, electronics telecommunications, biology, environment ... continue to increase" $\left[{ }^{11}\right]$. Therefore, in order to maintain environmental security in the current globalization

\footnotetext{
${ }^{7}$ The Communist Party of Vietnam: Document of the XI National Party Congress, National Communist Party Publishing House - ST, Hanoi 2011, p.42.

${ }^{8}$ Communist Party of Vietnam: Document of the 12th National Party Congress, National Youth Publishing House - ST, Hanoi 2016, pp.31 - 32.

${ }^{9}$ Communist Party of Vietnam: Document of the XII National Party Congress, National Youth Publishing House - ST, Hanoi 2016, pp.33 -34

${ }^{10}$ Communist Party of Vietnam: Document of the XII National Party Congress, National Youth Publishing House - ST, Hanoi 2016, pp.33 -34

${ }^{11}$ Communist Party of Vietnam: Document of the XII National Party Congress, National Youth Publishing House - ST, Hanoi 2016, pp. 182 - 183
}

conditions, Vietnam needs to properly address the following tasks:

First, strengthening international relations in the protection of national environmental security, because in the process of globalization, the relevant national environment is greatly influenced by the regional and global environment, so the cause of protecting environmental security in Vietnam is always associated with environmental security of Vietnam countries in the region and in the world. Promoting international cooperation on environmental security helps to overcome difficulties and limitations beyond the solvability of a country. First of all, to expand international cooperation on the environment in the spirit of respecting and seriously implementing the international conventions that our country has signed and acceded to. At the same time, absorb and disseminate the experiences and ways in environmental security protection. To take advantage of financial and technical support from international organizations for environmental security protection, especially to take advantage of projects from GEP (Global Environment Fund), to implement Effective environmental security protection, in line with regional and global environmental security goals. In which, focus on cooperation with other countries on issues such as biodiversity, protection of ecosystems, control of dangerous goods, and strengthening linkages between countries experts in global epidemic prevention and control, and share experiences of other countries, at the same time, promoting investment in scientific research in order to produce effective disease prevention vaccines.

Vietnam needs to proactively and take specific measures to cooperate on water resources in the Red River basin with China and cooperate to exploit the Mekong River with countries like Thailand, Laos and Cambodia, proceeding to formulate agreements, regulations on management, sharing and protection of water resources for international rivers, transnational water sources, maintaining security of the water environment.

Secondly, the Government of Vietnam promotes the work of information, communication and education to raise social awareness, first of all, party organizations, state agencies, enterprises, socio-political organizations. and the contingent of officials and party members on environmental security and responsibility for environmental security; making the task of protecting environmental security become awareness and self-conscious action of each member of society, becoming a cultural lifestyle of each person; make environmental security truly an important component of national security. At the same time, firmly grasp the view that investment in sustainable development does not compromise the environment for economic 
development, and does not attract investment at all costs; In the plans, plans, and projects of the economic development process, there must be measures and plans for environmental protection, to quickly integrate environmental security closely with socio-economic development policies.

Third, continue to research and step by step perfect the legal system on environmental protection and environmental security; to strengthen the capacity of the specialized agency for environmental protection, to establish a specialized national environmental security assurance agency. Regarding the legislative work, in addition to continuing to study, supplement and amend the law on environmental protection, it is necessary to study, formulate and issue laws on environmental security. At the same time, overcoming inadequacies in the state management of environmental security protection, especially in the application of tools and measures to prevent and control environmental pollution from the war environment assessment. strategy, environmental impact assessment, testing, certifying works, environmental protection measures, inspecting, inspecting, monitoring, monitoring waste sources ... ensuring these tools and measures are effective effective and effective in practice to strictly control sources of emissions into the environment. Besides, reviewing and consolidating the organizational apparatus, enhancing the capacity of state management agencies on the environment from the central to local levels to meet the increasingly large and complex requirements, tasks and outbreaks. incidents causing environmental pollution.
Fourthly, Vietnam needs to improve its capacity to monitor and warn climate and natural disasters through the expansion, development and modernization of the hydro-meteorological monitoring and forecasting system in the direction of combining monitoring. hydro-meteorological forecasts with climate monitoring and warnings; enhancing the development of information and data systems on climate and climate change to serve policy making and implementation of climate change response activities; continue to update and complete climate change scenarios announced before the period of socioeconomic development plan formulation in order to integrate and adjust plans in a timely manner.

Besides, continuing to study in order to change the structure of crops, animals, farming methods suitable to ecological characteristics of regions and localities in order to actively adapt to climate change; transforming livelihoods, jobs, ensuring social security for people, strengthening the system of risk insurance in agriculture and fisheries, especially in vulnerable regions due to climate change.

Fifth, strengthen the fight to prevent and combat crimes and violations of the law on environmental protection, especially the prevention and combat of transnational environmental pollution; prevent deforestation, hunting destroys animals and aquatic resources; combating smuggling and illegal import of industrial wastes, agricultural products, and food containing toxic preservatives, and acts of intentionally releasing toxic gas and waste into the environment. 